\title{
Respon Pertumbuhan dan Produksi Tanaman Melon (Cucumis melo L.) Akibat Aplikasi Pupuk Cair dan Pupuk kandang
}

\author{
Nursayuti ${ }^{1}$ \\ ${ }^{1}$ Dosen Program Atudi Agroteknologi Fakultas Pertanian Universitas Almuslim \\ Bireuen \\ Email: nursayuti1979@gmail.com
}

\begin{abstract}
Abstrak
Penelitian ini bertujuan untuk mengetahui pengaruh pupuk cair dan pupuk kandang terhadap pertumbuhan dan produksi tanaman melon (Cucumis melo L). Penelitian ini menggunakan Rancangan Acak Kelompok (RAK) dengan 2 (dua) faktor, yaitu faktor pupuk cair dan faktor pupuk kandang. Adapun parameter yang diamati dalam penelitian ini meliputi: tinggi tanaman, diameter batang, berat buah, diameter buah, dan jumlah buah Hasil penelitian menunjukkan bahwa pemberian pupuk cair berpengaruh sangat nyata terhadap tinggi tanaman, diameter batang pada umur 20, 40 dan 60 HST, berat buah dan jumlah buah. Pemberian pupuk cair terbaik pada dosis $\mathrm{O}_{2}(100 \mathrm{ml} / \mathrm{L}$ air $)$. Pemberian pupuk kandang berpengaruh sangat nyata terhadap tinggi tanaman pada umur 20 dan 40 HST, diameter batang pada umur 20, 40 dan 60 HST dan jumlah buah. Pemberian pupuk kandang terbaik padas dosis $\mathrm{K}_{2}$ (10 ton/ha). Terdapat interaksi yang nyata antara pemberian pupuk cair dan pupuk kandang terhadap tinggi tanaman umur 20 HST, diameter batang umur 60 HST dan jumlah buah.
\end{abstract}

Kata kunci : melon, pupuk cair, pupuk kandang, RAK.

\section{PENDAHULUAN}

Melon (Cucumis melo L.) adalah tanaman hortikultura yang bernilai ekonomi tinggi. Buah melon mempunyai harga yang relatif lebih tinggi dibanding tanaman hortikultura pada umumnya. Hal ini memberi banyak keuntungan kepada petani atau pengusaha pertanian tanaman melon dan ini memungkinkan adanya perbaikan tata perekonomian Indonesia, khususnya dari bidang pertanian.

Tingkat produksi melon di Indonesia yang semakin meningkat dapat dilihat dari laporan data Badan Pusat Statistik (2017) bahwa produksi tanaman melon pada tahun 2014 hanya 125.207 ton kemudian meningkat pada tahun 2015 dengan angka produksi 150.347 ton dan pada tahun 2016 produksi melon mencapai 177.887 ton. Walaupun produksi melon mengalami peningkatan disetiap tahunnya, tetapi jumlahnya tetap tidak memenuhi kebutuhan konsumen melon di daerah Indonesia.

Berdasarkan data BPS Bireuen tahun 2016 jumlah hasil produksi tanaman melon yang diperoleh dengan luas lahan $1.200 \mathrm{~m}^{2}$ adalah sebanyak 8 ton, dengan harga jual melon sebesar $\mathrm{Rp} 10 \mathrm{ribu} / \mathrm{Kg}$. Maka keuntungan yang diperoleh dengan modal sebesar Rp 20 juta adalah Rp 60 juta. Untuk luas $1.200 \mathrm{~m}^{2}$ ditanami dengan 2.200 batang melon. 
Menurut Fitri (2011), konsumsi buah melon semakin meningkat seiring dengan peningkatan pola makan penduduk Indonesia yang membutuhkan buah segar sebagai salah satu sumber gizi sehari-hari, konsumsi buah melon di Indonesia diperkirakan akan meningkat hingga mencapai 1,34$1,5 \mathrm{~kg} / \mathrm{kapita} /$ tahun. Melon yang awalnya hanya dikenal sebagai buah untuk konsumsi masyarakat golongan atas sekarang sudah merakyat kesemua lapisan masyarakat meski belum mampu menjangkau ke pelosok Indonesia. Wijoyo (2009), menyatakan meskipun volume permintaan buah melon tinggi, tetapi seringkali permintaan pasar domestik saja tidak terpenuhi. Keterbatasan produksi melon ini diakibatkan oleh masih sedikitnya daerah sentra penanaman melon di Indonesia.

Rendahnya pengetahuan petani di Indonesia tentang pemupukan dengan menggunakan pupuk cair dan pupuk kandang dapat digunakan sebagai salah satu alternatif sumber pupuk bagi kehidupan hortikultura terutama tanaman melon, dengan kurangnya pemupukan yang kurang efektif akan mengakibatkan produksi melon berkurang, karena pertumbuhan produksi tanaman melon sangat dipengaruhi bagaimana cara penggunaan pupuk pada tanaman (Hanafiah, 2007).

Manfaat pupuk cair ialah meningkatkan kesuburan tanah serta memperbaiki dan meningkatkan kualitas organik di dalam tanah, sehingga tanah atau lahan menjadi lebih remah, gembur dan tidak liat bahkan keras serta mengurangi polusi dan dampak sampah di lingkungan. Pupuk kandang merupakan salah satu sumber pupuk cair yang memiliki kandungan hara relatif lengkap dibandingkan dengan pupuk alam lainnya maupun dengan pupuk buatan. Keistimewaan yang dimiliki pupuk kandang adalah dapat memperbaiki sifat biologi, fisik, dan kimia tanah, mampu meningkatkan kesuburan tanah, memperbaiki struktur tanah, menyediakan hara mikro dan meningkatkan kadar bahan organik sejak berabad-abad silam. Pemanfaatan pupuk kandang secara langsung juga berkaitan dengan kadar air yang tinggi (Lingga dan Marsono, 2004).

Penelitian ini bertujuan untuk mengetahui pengaruh pupuk cair dan pupuk kandang terhadap pertumbuhan dan produksi tanaman melon (Cucumis melo L).

\section{METODE PENELITIAN}

Penelitian ini dilakukan di Geulanggang Rayeuk Kecamatan Kuta Blang Kabupaten Bireuen dengan 54 mdpl yang berlangsung pada bulan April sampai dengan Juni 2018.

Alat yang digunakan antara lain polibag, timbangan digital, ember, sprayer, penggaris, benang, kertas label, dan alatalat tulis menulis.. Bahan yang digunakan antara lain: Bibit melon hibrida varietas sonya, pupuk cair Nasa, pupuk kandang sapi dan fungisida antracol.

Penelitian ini menggunakan Rancangan Acak Kelompok (RAK) dengan 2 (dua) faktor dan 3 (tiga) ulangan dimana setiap unit percobaan terdiri dari: Faktor I Pupuk Cair (O) terdiri dari 3 taraf : $\mathrm{O}_{0}$ : Kontrol (Tanpa Pupuk Cair), $\mathrm{O}_{1}: 50 \mathrm{~mL} / \mathrm{L}$ air, dan $\mathrm{O}_{2}$ : $100 \mathrm{~mL} / \mathrm{L}$ air. Sedangkan Faktor II Pupuk Kandang (K) terdiri dari 3 taraf : $\mathrm{K}_{0}$ : Kontrol (Tanpa Pupuk Kandang), $\mathrm{K}_{1}$ : Pupuk Kandang 5 ton/ha (500 gr/tanaman), dan $\mathrm{K}_{2}$ : Pupuk Kandang 10 ton/ha (1.000 gr/tanaman).

Adapun model matematis yang digunakan dalam penelitian adalah: $Y_{i j k}=\mu+\tau_{i}+O_{j}+K_{k}+(O K)_{j k}+\varepsilon_{i j k .}$. Parameter yang diamati meliputi: tinggi 
tanaman, diameter batang, berat buah, Melon.

diameter buah, dan jumlah buah

\section{HASIL DAN PEMBAHASAN}

\section{Pengaruh Pemberian Pupuk Cair Nasa dan Pupuk Kandang.}

\section{Tinggi Tanaman Umur 20, 40 dan 60 HST}

Berdasarkan dari semua hasil uji $\mathrm{F}$ pada analisis sidik ragam, terdapat beberapa pengamatan ada interaksi yang sangat nyata antara pupuk cair dan pupuk kandang terhadap tinggi tanaman pada umur 20 HST. Rata-rata tinggi tanaman melon pada umur 20 HST akibat perlakuan pupuk cair dan pupuk kandang disajikan pada Tabel 1.

Tabel 1. Rata-rata tinggi tanaman melon pada umur 20 HST akibat perlakuan pupuk cair dan pupuk kandang.

\begin{tabular}{cccc}
\hline \multirow{2}{*}{ Perlakuan } & \multicolumn{3}{c}{ Tinggi Tanaman 20 HST } \\
\cline { 2 - 4 } & $\mathrm{K}_{0}$ & $\mathrm{~K}_{1}$ & $\mathrm{~K}_{2}$ \\
\hline $\mathrm{O}_{0}$ & $60.2^{\mathrm{aA}}$ & $68.1^{\mathrm{bB}}$ & $72.2^{\mathrm{cB}}$ \\
$\mathrm{O}_{1}$ & $60.9^{\mathrm{aA}}$ & $63.8^{\mathrm{aA}}$ & $63.7^{\mathrm{AA}}$ \\
$\mathrm{O}_{2}$ & $63.8^{\mathrm{aA}}$ & $65.7^{\mathrm{aB}}$ & $72.6^{\mathrm{bB}}$ \\
\hline
\end{tabular}

BNJ $_{0,05}$

3.6

Keterangan : Angka yang diikuti oleh huruf yang sama pada lajur dan kolom yang sama berbeda tidak nyata pada uji BNJ pada taraf $(0,05)$. Huruf besar dibaca vertikal dan huruf kecil dibaca horizontal.

Tabel 1 menunjukkan bahwa tinggi tanaman melon akibat pemberian antara pupuk cair Nasa dan pupuk kandang terdapat pengaruh yang sangat nyata pada umur 20 HST, tapi tidak berpengaruh sangat nyata pada umur 40 dan 60 HST. Hal ini diduga pemberian dosis pupuk cair dan pupuk kandang mampu berkondistribusi dengan baik pada tanaman melon sehingga mampu mendukung pertumbuhan tinggi tanaman melon pada umur 20 HST.

Hal ini disebabkan karena perakaran tanaman melon mampu berkembang sempurna dan dapat menyerap unsur hara secara maksimal, sehingga unsur hara yang diberikan belum bisa dimanfaatkan oleh tanaman secara maksimal untuk melakukan pertumbuhan. Selain itu, hasil analisis menunjukkan bahwa kandungan unsur $\mathrm{N}$ dan $\mathrm{K}$ pada pupuk kandang yang sempurna, sehingga mampu memacu tinggi tanaman. Pemberian pupuk cair Nasa memberikan hasil yang positif pada tinggi tanaman melon. Hal tersebut terlihat dari tinggi tanaman yang memberikan hasil yang lebih baik dibandingkan dengan tanpa pemupukan. Nitrogen dibutuhkan dalam jumlah yang relatif besar pada setiap tahap pertumbuhan, khususnya pada pertumbuhan vegetatif seperti pertumbuhan tinggi tanaman melon (Venita dkk., 2007)

Unsur $\mathrm{N}$ sangat diperlukan oleh tanaman untuk pembentukan klorofil, dan klorofil sendiri merupakan akseptor dalam 
penyerapan cahaya matahari yang diperlukan tanaman dalam proses fotosintesis agar dapat menghasilkan fotosintat yang diperlukan tanaman untuk melakukan pertumbuhan dan juga perkembangan. Menurut Ashari (2015), nitrogen di dalam tanaman berfungsi sebagai penyusun protoplasma, molekul klorofil, asam nukleat dan asam amino yang merupakan penyusun protein, jika terjadi difisiensi nitrogen dapat menyebabkan pertumbuhan vegetatif maupun generatif tanaman terganggu.

\section{Diameter Batang Umur 60 HST}

Berdasarkan dari semua hasil uji $\mathrm{F}$ pada analisis sidik ragam, terdapat beberapa pengamatan ada interaksi yang sangat nyata antara pupuk cair dan pupuk kandang terhadap diameter batang pada umur 60 HST.

Rata-rata diameter batang tanaman melon pada umur 60 HST akibat perlakuan pupuk cair dan pupuk kandang disajikan pada Tabel 2.

Tabel 2. Rata-rata diameter batang tanaman melon pada umur 60 HST akibat perlakuan pupuk cair dan pupuk kandang.

\begin{tabular}{cccc}
\hline \multirow{2}{*}{ Perlakuan } & \multicolumn{3}{c}{ Diameter Batang 60 HST } \\
\cline { 2 - 4 } & $\mathrm{K}_{0}$ & $\mathrm{~K}_{1}$ & $\mathrm{~K}_{2}$ \\
\hline $\mathrm{O}_{0}$ & $3.2^{\mathrm{aA}}$ & $3.1^{\mathrm{aA}}$ & $2.8^{\mathrm{aA}}$ \\
$\mathrm{O}_{1}$ & $3.1^{\mathrm{aA}}$ & $3.9^{\mathrm{bB}}$ & $4.6^{\mathrm{cB}}$ \\
$\mathrm{O}_{2}$ & $3.9^{\mathrm{aB}}$ & $3.7^{\mathrm{aA}}$ & $4.5^{\mathrm{bB}}$ \\
\hline
\end{tabular}

BNJ 0,05

Keterangan : Angka yang diikuti oleh huruf yang sama pada lajur dan kolom yang sama berbeda tidak nyata pada uji BNJ pada taraf $(0,05)$. Huruf besar dibaca vertikal dan huruf kecil dibaca horizontal.

Tabel 2 menunjukkan bahwa diameter batang tanaman melon akibat pemberian antara pupuk cair Nasa dan pupuk kandang terdapat pengaruh yang sangat nyata pada umur 60 HST, tapi tidak berpengaruh sangat nyata pada umur 20 dan 40 HST. Hal ini diduga pemberian dosis pupuk cair Nasa dan pupuk kandang mampu berkontribusi dengan baik pada tanaman melon sehingga mampu mendukung pertumbuhan tinggi tanaman melon pada umur 60 HST.

Interaksi pemberian pupuk cair Nasa dan pupuk kandang memberikan pengaruh yang sangat sangat nyata terhadap diameter batang tanaman melon. Pemberian pupuk cair Nasa akan meningkatkan kesuburan tanah serta memperbaiki dan meningkatkan kualitas organik di dalam tanah, sehingga tanah atau lahan menjadi lebih remah, gembur dan tidak liat bahkan keras serta mengurangi polusi dan dampak sampah di lingkungan dan pemberian pupuk kandang juga akan meningkatkan hara serta mengikat unsur-unsur mikro yang bersifat racun serta memperbaiki sifat fisik tanah.Pupuk Cair Nasa juga dapat memacu pertumbuhan tanaman dan akar, merangsang pengumbian, pembungaan dan pembuahan serta mengurangi kerontokan bunga dan buah (mengandung hormon / ZPT Auksin, giberellin, dan sitokinin)

$$
\text { Pupuk kandang akan }
$$
meningkatkan kesuburan tanah dan 
merangsang perakaran yang sehat. Pupuk kandang memperbaiki struktur tanah dengan meningkatkan kandungan bahan organik tanah dan akan meningkatkan kemampuan tanah untuk mempertahankan kandungan air tanah. Tanaman yang dipupuk dengan pupuk kandang cenderung lebih baik kualitasnya daripada tanaman yang dipupuk dengan pupuk kimia. Samekto (2016), menyatakan dengan bahwa pemberian pupuk kandang mampu mengurangi kepadatan tanah sehingga memudahkan perkembangan akar dan kemampuannya dalam penyerapan hara. Peranan bahan organik dalam pertumbuhan tanaman dapat secara langsung, atau sebagian besar mempengaruhi tanaman melalui perubahan sifat dan ciri tanah.

Hal ini disebabkan dengan pemberian pupuk cair Nasa dapat meningkatkan ketersediaan dan serapan unsur hara yang sangat diperlukan untuk pembentukan senyawa organik seperti karbohidrat, protein dan lipida. Senyawa-senyawa tersebut berperan dalam pembesaran diameter batang yang lebih ideal. Selanjutnya dijelaskan oleh Dwidjoseputro (2011), bahwa tanaman akan tumbuh subur dan memberikan hasil yang baik jika unsur hara yang dibutuhkannya tersedia dalam jumlah cukup dan seimbang.

\section{Berat Buah}

Berdasarkan dari hasil uji $\mathrm{F}$ pada analisis sidik ragam, tidak ada interaksi yang nyata antara perlakuan pupuk cair dan pupuk kandang terhadap berat buah tanaman melon. Rata-rata berat buah tanaman melon pada umur 60 HST akibat perlakuan pupuk cair dan pupuk kandang disajikan pada Tabel 3.

Tabel 3. Rata-rata berat buah tanaman melon pada umur 60 HST akibat perlakuan pupuk cair dan pupuk kandang.

\begin{tabular}{cccc}
\hline \multirow{2}{*}{ Perlakuan } & \multicolumn{3}{c}{ Jumlah Buah } \\
\cline { 2 - 4 } & $\mathrm{K}_{0}$ & $\mathrm{~K}_{1}$ & $\mathrm{~K}_{2}$ \\
\hline $\mathrm{O}_{0}$ & 2.0 & 2.2 & 2.4 \\
$\mathrm{O}_{1}$ & 2.4 & 2.1 & 2.2 \\
$\mathrm{O}_{2}$ & 2.4 & 2.4 & 2.8 \\
\hline Rataan & 2.2 & 2.2 & 2.4 \\
\hline
\end{tabular}

Tabel 3 menunjukkkan bahwa pemberian pupuk cair Nasa dan pupuk kandang tidak berpengaruh nyata terhadap berat buah melon. Namun secara statistik perlakuan terbaik dijumpai pada perlakuan $\mathrm{O}_{2} \mathrm{~K}_{2}$ dengan nilai 2.8. Hal ini diduga karena unsur dan kandungan yang terdapat didalam pupuk cair nasa dan pupuk kandang tidak dapat digunakan secara maksimal sehingga tidak dapat meningkatkan berat buah. Diameter Buah

Berdasarkan dari hasil uji $\mathrm{F}$ pada analisis sidik ragam, tidak ada interaksi yang nyata antara perlakuan pupuk cair dan pupuk kandang terhadap berat buah tanaman melon.

Rata-rata diameter buah tanaman melon pada umur 60 HST akibat perlakuan pupuk cair dan 
pupuk kandang disajikan pada

Tabel 4.

Tabel 4. Rata-rata diameter buah tanaman melon pada umur 60 HST akibat perlakuan pupuk cair dan pupuk kandang.

\begin{tabular}{cccc}
\hline \multirow{2}{*}{ Perlakuan } & \multicolumn{3}{c}{ Jumlah Buah } \\
\cline { 2 - 4 } & $\mathrm{K}_{0}$ & $\mathrm{~K}_{1}$ & $\mathrm{~K}_{2}$ \\
\hline $\mathrm{O}_{0}$ & 48.0 & 53.2 & 50.8 \\
$\mathrm{O}_{1}$ & 54.4 & 51.3 & 53.2 \\
$\mathrm{O}_{2}$ & 50.8 & 55.0 & 55.2 \\
\hline Rataan & 51.06 & 53.1 & 53.00 \\
\hline
\end{tabular}

Tabel 4 menunjukkkan bahwa pemberian pupuk cair Nasa dan pupuk kandang tidak berpengaruh nyata terhadap Diameter buah melon. Namun secara statistic perlakuan terbaik dijumpai pada perlakuan $\mathrm{O}_{2} \mathrm{~K}_{2}$ dengan nilai 55.2. Hal ini diduga karena unsur dan kandungan hormon yang terdapat didalam pupuk cair nasa dan pupuk kandang tidak dapat digunakan secara maksimal sehingga tidak dapat meningkatkan diameter buah buah melon.

\section{Jumlah Buah}

Berdasarkan dari semua hasil uji $\mathrm{F}$ pada analisis sidik ragam, terdapat beberapa pengamatan ada interaksi yang sangat nyata antara pupuk cair dan pupuk kandang terhadap jumlah buah. Rata-rata jumlah buah akibat perlakuan pupuk cair dan pupuk kandang disajikan pada Tabel 5.

Tabel 5. Rata-rata jumlah buah akibat perlakuan pupuk cair dan pupuk kandang.

\begin{tabular}{cccc}
\hline \multirow{2}{*}{ Perlakuan } & \multicolumn{3}{c}{ Jumlah Buah } \\
\cline { 2 - 4 } & $\mathrm{K}_{0}$ & $\mathrm{~K}_{1}$ & $\mathrm{~K}_{2}$ \\
\hline $\mathrm{O}_{0}$ & $2.7^{\mathrm{aA}}$ & $3.1^{\mathrm{aA}}$ & $2.8^{\mathrm{aA}}$ \\
$\mathrm{O}_{1}$ & $3.1^{\mathrm{aA}}$ & $3.0^{\mathrm{aA}}$ & $4.6^{\mathrm{bB}}$ \\
$\mathrm{O}_{2}$ & $3.9^{\mathrm{aB}}$ & $3.7^{\mathrm{aB}}$ & $4.0^{\mathrm{aA}}$ \\
\hline
\end{tabular}

BNJ 0,05

0.6

Keterangan : Angka yang diikuti oleh huruf yang sama pada lajur dan kolom yang sama berbeda tidak nyata pada uji BNJ pada taraf $(0,05)$. Huruf besar dibaca vertikal dan huruf kecil dibaca horizontal.

Tabel 5 menunjukkan bahwa jumlah buah tanaman melon akibat pemberian antara pupuk cair Nasa dan pupuk kandang terdapat pengaruh yang sangat nyata. Hal ini diduga pemberian dosis pupuk cair Nasa dan pupuk kandang mampu berkondistribusi dengan baik pada tanaman melon sehingga mampu mendukung pertumbuhan jumlah buah tanaman melon. Pemberian pupuk kandang mampu membantu proses penyerapan unsur hara dan mineral dalam tanah. 
Menurut Sitompul dan Guritno (2015), tanaman yang masih muda sampai fase pembentukan bunga membutuhkan pupuk yang memiliki kandungan $\mathrm{N}$ tinggi serta kandungan unsur hara mikro B, Mo, $\mathrm{Cu}, \mathrm{Zn}$, dan $\mathrm{Mn}$. Unsur hara mikro yaitu unsur hara yang dibutuhkan tanaman dalam jumlah yang relatif sedikit namun mutlak diperlukan. Jika penggunaannya berlebihan justru dapat menjadi racun sedangkan unsur hara makro yaitu unsur hara yang dibutuhkan tanaman dalam jumlah yang cukup banyak.

Tanaman yang mempunyai jumlah buah yang lebih banyak pada awal pertumbuhannya, tanaman akan lebih cepat tumbuh karena kemampuan menghasilkan fotosintesa yang lebih tinggi dari tanaman dengan jumlah buah yang lebih rendah, jumlah daun tanaman akan mempengaruhi pertumbuhan jaringan tanaman yang lain (Sitompul dan Guritno (2015).

Seperti yang dikatakan Rinsema (2013), bahwa untuk mendapatkan hasil yang tinggi dan kualitas yang baik, maka syarat utama adalah tanaman harus mendapat unsur hara yang cukup selama pertumbuhan.

Lingga dan Marsono (2016) menambahkan bahwa ada beberapa unsur hara yang terkandung didalam pupuk organik cair Nasa yang bermanfaat bagi jumlah buah yaitu Fosfor (P) yang dapat mempercepat pembungaan, Kalium (K) yang membantu bunga agar tidak mudah rontok dan Boron (B) yang berfungsi memperbanyak jumlah bunga yang berakibat pula pada jumlah buah yang terbentuk.

POC NASA berfungsi multiguna, kandungan unsur hara mikro dalam 1 lt POC NASA mempunyai fungsi setara dengan 1 ton pupuk kandang. Kandungan Humat Fulvat yang dimiliki POC NASA berangsur-angsur akan memperbaiki konsistensi (kegemburan) tanah yang keras.

\section{Kandungan Hormon/ZPT}

(Zat Pengatur Tumbuh)/Auksin, Giberelin dan sitokinin akan mempercepat perkecambahan biji, pertumbuhan akar, perbanyakan umbi, fase vegetatif/pertumbuhan tanaman serta memperbanyak bunga dan buah dan mengurangi kerontokan.

\section{KESIMPULAN DAN SARAN}

\section{Kesimpulan}

Terdapat interaksi yang nyata antara pemberian pupuk cair Nasa dan pupuk kandang terhadap tinggi tanaman pada umur 20 HST, diameter batang pada umur 60 HST dan jumlah buah Melon, akan tetapi tidak terdapat interaksi yang nyata pada tinggi tanaman umur 40 dan 60 HST, diameter batang pada umur 20 dan 40 HST, berat buah dan diameter buah. Kombinasi perlakuan terbaik dijumpai pada konsentrasi pupuk cair Nasa $100 \mathrm{~mL} / \mathrm{L}$ air dan dosis pupuk kandang 10 ton/ha $\left(\mathrm{O}_{2} \mathrm{~K}_{2}\right)$.

\section{Saran}

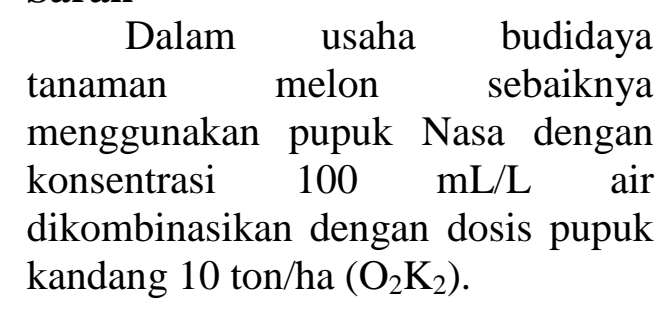

\section{DAFTAR PUSTAKA}

Badan Pusat Statistika. 2017. Aceh Dalam Rangka 2017. Biro Pusat Statistika (BPS) Aceh. 
Dwidjoseputro, D. 2010. Dasar dasar Mikrobiologi. Djambatan. Jakarta.

Fitri, M., Nurdin, A., Warnita. 2011. Pengaruh pemberian beberapa konsentrasi pupuk pelengkap cair Nutrifram AG terhadap pertumbuhan dan hasil tanaman melon (Cucumis melo L.). Jurnal Penelitian Agronomi 4(3):148-153.

Hanafiah, K.A. 2007. Dasar-dasar Ilmu Tanah. Jakarta : Raja Grafindo.

Lingga, P., Marsono. 2015. Petunjuk Penggunaan Pupuk. Penebar Swadaya.

Rinsema, W.P. 1986. Pupuk dan Cara Pemupukan. Bharata Karya Aksara. Jakarta.

Samekto, R. 2006. Pupuk Kandang. Citra Aji Parama.Yogyakarta.

Sitompul, S.M., Guritno, B. 1995. Analisis Pertumbuhan Tanaman. UGM Press. Yogyakarta.

Venita,Y., Armaini. 2007. Pengaruh bokhasi dan nitrogen dalam meningkatkan kualitas Bibit Cabai Merah di Pembibitan. Laporan Penelitian. Lembaga Penelitian Universitas Riau Pekanbaru.

Wijoyo, P.M. 2009. Panduan Praktis Budidaya Melon. Bee Media Indonesia. Jakarta. 